\title{
Synthesis of Diphenyl Pyridazinone-based flexible system for conformational studies through weak noncovalent interactions: Application in DNA binding
}

\author{
RANJEET KUMAR, PRAVEEN SINGH, ARCHANA GAURAV, PRATIMA YADAV, \\ RANJANA S KHANNA and ASHISH KUMAR TEWARI* \\ Department of Chemistry (Centre of Advanced Studies), Institute of Science, Banaras Hindu University, \\ Varanasi, 221005, India \\ e-mail: ashishtewarichem@gmail.com
}

MS received 21 September 2015; revised 15 February 2016; accepted 16 February 2016

\begin{abstract}
This paper reports conformational studies of pyridazinone-based flexible dimer connected through diethylamine linker. The conformational studies have been done by X-ray crystal structure and DFT calculation. Further, after crystallization, the compound has shown two types of crystals, one is hydrated and another one is non-hydrated. The hydrated and non-hydrated crystals showed difference in their conformation due to the presence of water in crystal lattice of hydrated crystal. The difference in their conformation has been proved by crystallographic studies, DSC curves and detailed analysis of Hirshfeld surfaces and fingerprint plots facilitating a comparison of intermolecular interactions. Along with conformational studies, this compound also showed DNA binding, as revealed in docking simulation studies.
\end{abstract}

Keywords. Single crystal structure; DFT calculation; Hirshfeld surfaces; fingerprint analysis; docking simulation; DNA binding.

\section{Introduction}

Several groups have quantified noncovalent interactions to rationalize their observations across chemical sciences. ${ }^{1-4}$ The noncovalent interactions have been exploited to prepare topologically complex molecules, to control the enantioselectivity of reactions and for asymmetric synthesis. ${ }^{5,6}$ In biological systems, noncovalent interactions have been identified as key factors in determining the structural and molecular recognition properties of nucleic acids, peptides and proteins as well as stabilization of DNA/RNA structures. ${ }^{7-10}$ Further, noncovalent interactions is also applicable in the field of DNA binding with ligands. ${ }^{11}$ These noncovalent interactions range from conventional strong interactions $(\mathrm{O}-\mathrm{H} \cdots \mathrm{O}, \mathrm{N}-\mathrm{H} \cdots \mathrm{O})$ to unconventional weak interactions $(\mathrm{C}-\mathrm{H} \cdots \mathrm{O}, \mathrm{C}-\mathrm{H} \cdots \mathrm{N})$ as well as $\pi$ interactions $(\mathrm{O}-\mathrm{H} \cdots \pi, \mathrm{N}-\mathrm{H} \cdots \pi, \mathrm{C}-\mathrm{H} \cdots \pi)$, etc. ${ }^{12-15}$ The binding affinity of DNA with ligands through noncovalent interaction occurs via several modes, such as, (i) electrostatic attractions with the anionic sugarphosphate backbone of DNA, (ii) interactions with the DNA major groove, (iii) interactions with the DNA minor groove, (iv) intercalation between base pairs via the DNA major groove, (v) intercalation between base

\footnotetext{
*For correspondence
}

pairs via the DNA minor groove, (vi) a threading intercalation mode, etc. ${ }^{16-18}$ Normally, binding mode of ligands with DNA for most favourable free energy of complex formation depends on structural features of flexible ligands. ${ }^{17}$

This work deals with synthesis of symmetrical diphenyl pyridazinone based flexible dimer, namely, 2,2'-(azanediylbis(ethane-2,1-diyl))bis(3-oxo5,6-diphenyl-2,3-dihydropyridazine-4-carbonitrile) (3) (scheme 1), linked through diethylamine spacer for conformational studies through crystal structure in solid state. The dimer $\mathbf{3}$ contained strong non-covalent sites and has enough flexibility to adjust the almost stable folded conformation during crystallization using such a long spacer. Therefore, molecule $\mathbf{3}$ has shown DNA binding ability due to flexibility and intramolecular folding. Normally, folding has been seen in propylene spacer based molecules, which was quantified for the first time by Leonard et al., between two hetero aromatic cores. ${ }^{19}$ Since 1995, extensive X-ray crystallographic studies by Avasthi et al., established the utility of propylene linker, as suggested by Leonard et al., ${ }^{19}$ in order to observe intramolecular folding between two similar/different arene residues. ${ }^{1,20}$ But interestingly, folding in the above mentioned systems was lost when the 'propylene linker' was replaced by tetramethylene linker ${ }^{21}$ or by pentamethylene linker. ${ }^{22}$ 

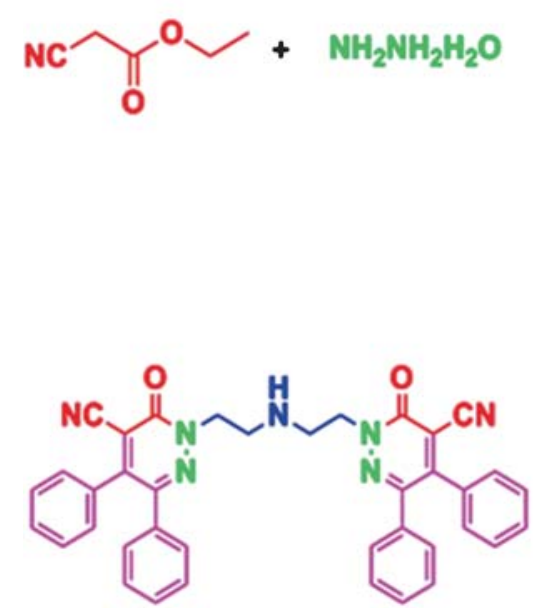

Yield: $78 \%$

3
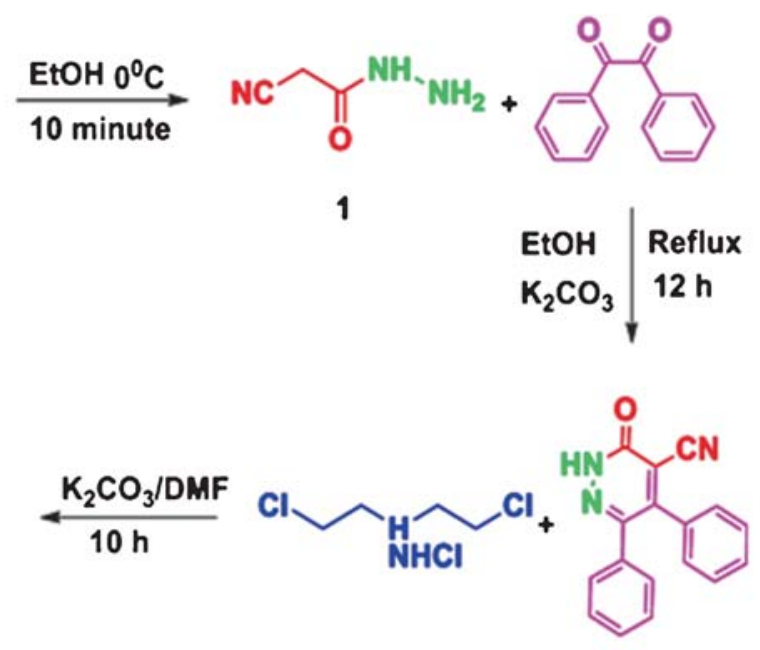

Yield: $91 \%$

Scheme 1. Procedure for preparation of compound 3.

\section{Experimental}

\subsection{General}

All reactions were monitored by thin layer chromatography (TLC) over silica gel G UV active plates. The melting points were recorded on an electrically heated block and are uncorrected. The NMR spectra were recorded on Jeol $300 \mathrm{MHz}$ FT spectrometer equipped with a $5 \mathrm{~mm}$ dual probe and a $6 \mathrm{~mm}$ multinuclear inverse probe head with a Z-shielded gradient using TMS as an internal reference [chemical shift in $\delta$ (parts per million)].

\subsection{Synthesis}

Compounds $\mathbf{1}$ and $\mathbf{2}$ were synthesized according to literature procedures. ${ }^{23}$

2.2a Synthesis of 2,2'-(azanediylbis(ethane-2,1-diyl)) bis(3-oxo-5,6-diphenyl-2,3-dihydropyridazine-4-carbonitrile) (3): In a $100 \mathrm{~mL}$ round-bottom flask, compound 2 (0.5 g, $0.003 \mathrm{~mol})$ was dissolved in dry DMF and the mixture stirred for $15 \mathrm{~min}$. Anhydrous potassium carbonate $(0.46 \mathrm{~g}, 0.003 \mathrm{~mol})$ was added and the mixture stirred for $2 \mathrm{~h}$. Bis(2-chloroethyl)amine hydrochloride $(0.44 \mathrm{~g}, 0.002 \mathrm{~mol})$ was added to the mixture and stirred for $20 \mathrm{~h}$. Completion of the reaction was monitored by TLC. DMF was removed through a rotary evaporator, and ice-cold water was added. Precipitate was filtered with a Buchner funnel. The compound was recrystallized, which yielded an almost pure product: M.p.: $270-275^{\circ}$ C.Yield: (78\%). ${ }^{1} \mathrm{H}$ NMR $\left(300 \mathrm{MHz}, \mathrm{CDCl}_{3}\right): \delta 2.16(\mathrm{~s}, 1 \mathrm{H}), \delta 3.25-3.27$ (t, 4H,
$\mathrm{CH}_{2}-\mathrm{N}$,), $\delta$ 4.42-4.46 (t, 4H, $\mathrm{CH}_{2}-\mathrm{N}$ py), 7.08-7.41 $(\mathrm{m}, 20 \mathrm{H}, \mathrm{Ar}-\mathrm{H}) .{ }^{13} \mathrm{C}$ NMR $\left(300 \mathrm{MHz}, \mathrm{CDCl}_{3}\right): \delta$ 45.78, 47.26, 113.32, 113.60, 128.17, 128.70, 128.95, $129.17,130.38,132.46,134.17,145,94,150.93$, 157.11, $(\mathrm{m} / \mathrm{z})=415.24(\mathrm{M}+\mathrm{H})$ Anal. Calcd $(\%)$ for $\mathrm{C}_{38} \mathrm{H}_{29} \mathrm{~N}_{7} \mathrm{O}_{2} \mathrm{C}, 74.13 ; \mathrm{H}, 4.74 ; \mathrm{N}, 15.92$ : O, 5.2 Found (\%) 73.83; H, 4.94; N, 15.20: O, 5.72.

\section{$2.3 X$-ray Data Collection and Refinements}

Single-crystal X-ray structure, space group, unit cell dimensions, and intensity data were determined from single crystal X-ray diffraction data collected at ambient temperature on Oxford Diffraction X-calibur CCD diffractometer using graphite monochromated Mo K $\alpha$ radiation $(\lambda=0.71073 \AA)$. The structures were determined by direct methods using SHELXS-97 and refined on F2 by a full-matrix least-squares technique using SHELXL-97. ${ }^{24}$ The packing diagrams were generated using Mercury version 3.1. PLATON was used for the analysis of bond lengths, bond angles, and other geometrical parameters. Non-hydrogen atoms were refined anisotropically, and hydrogen atoms were geometrically fixed with thermal parameters equivalent to 1.2 times that of the atom to which they are bonded. Molecular diagrams for all compounds were prepared using ORTEP. $^{25}$

\subsection{Theoretical Study}

In order to investigate the conformational stability in the gaseous state, single point and optimized energies have been calculated using the DFT-D method using Gaussian 09. ${ }^{26}$ 


\subsection{Hirshfeld Surface Analysis}

The Hirshfeld surface emerged from an attempt to define the space occupied by a molecule in a crystal for the purpose of partitioning the crystal electron density into molecular fragments. Graphical tools based on the Hirshfeld surface and the associated twodimensional (2D) fingerprint plot offered considerable promise for exploring packing modes and intermolecular interactions in molecular crystals. Calculations were performed using the Crystal Explorer package. ${ }^{27}$

\subsection{Crystallization Experiments}

The hydrated crystal of diphenyl pyridazinone-based flexible dimer, 2,2'-(azanediylbis(ethane-2,1-diyl))bis(3oxo-5,6-diphenyl-2,3-dihydropyridazine-4-carbonitrile) (3a) was crystallized in a mixture of chloroform and methanol in ratio of (1:1) by slow evaporation at room temperature.

The non-hydrated crystal of diphenyl pyridazinonebased flexible dimer, 2,2'-(azanediylbis(ethane-2,1-diyl)) bis(3-oxo-5,6-diphenyl-2,3-dihydropyridazine-4-carbonitrile) (3b) was crystallized in a mixture of ethanol and ethyl acetate $(1: 2)$ by slow evaporation at room temperature.

\section{Results and Discussion}

\subsection{Crystallography Studies}

In this section we shall discuss about crystallographic studies of compound $\mathbf{3}$, particularly the intramolecular interactions that stabilized the molecule in folded U-shaped conformation. The compound $\mathbf{3}$ has two crystals, which are $\mathbf{3 a}$ hydrated and $\mathbf{3 b}$ non-hydrated. Hydrated crystal $\mathbf{3 a}$ and non-hydrated crystal $\mathbf{3 b}$ are different in their conformation as water is trapped in crystal lattice of 3a. The crystal structure of diphenyl pyridazinone-based flexible dimer, 2,2'(azanediylbis(ethane-2,1-diyl))bis(3-oxo-5,6-diphenyl2,3-dihydropyridazine-4-carbonitrile), are shown in hydrated (3a) and non-hydrated (3b) crystals (figures 1 and S1 in Supplementary Information). The hydrated crystal 3a was found to be P21/n monoclinic space group with the following values: cell lengths are as follows: $\mathrm{a}=16.2553(12) \AA, \mathrm{b}=9.4909(7) \AA, \mathrm{c}=$ 23.076(2) $\AA$ and cell angles $\left(^{\circ}\right)$ are $\alpha=90.00, \beta=$ 105.213 (8), $\gamma=90.00, Z=4$ and $V=3435.3$ (5) $\AA$ Non-hydrated crystal $\mathbf{3 b}$ was found to be monoclinic with the space group the $\mathrm{P} 21 / \mathrm{c}$ with the following values: cell lengths $a=17.046(3) \AA, b=9.3679(12) \AA$, $\mathrm{c}=20.873(4) \AA$ and cell angles $\left({ }^{\circ}\right)$ are $\alpha=90.00, \beta=$ 106.887(18), $\gamma=90.00, \mathrm{Z}=4$ and $\mathrm{V}=3189.4(10) \AA$ (Table 1).

The crystal structure of molecule $\mathbf{3}$ ( $\mathbf{3 a}$ and $\mathbf{3 b}$ ) revealed that the molecule is in folded conformation, which is controlled by a combination of intramolecular $\mathrm{N}-\mathrm{H} \cdots \mathrm{N}, \mathrm{N}-\mathrm{H} \cdots \mathrm{O}, \mathrm{C}-\mathrm{H} \cdots \mathrm{O}, \mathrm{C}-\mathrm{H} \cdots \mathrm{N}$ and $\mathrm{N}-$ $\mathrm{H} \cdots \pi$ interactions. ${ }^{28,29}$ The intramolecular $\mathrm{N}-\mathrm{H} \cdots \mathrm{N}$, $\mathrm{N}-\mathrm{H} \cdots \mathrm{O}, \mathrm{C}-\mathrm{H} \cdots \mathrm{O}, \mathrm{C}-\mathrm{H} \cdots \mathrm{N}$ and $\mathrm{N}-\mathrm{H} \cdot \cdots \pi$ interactions occurred between diethylene amine linker with pyridazinone moieties, and another $\mathrm{C}-\mathrm{H} \cdots \mathrm{O}$ and $\mathrm{C}$ $\mathrm{H} \cdots \mathrm{N}$ interaction occurred between phenyl hydrogen of one pyridazinone moieties with oxygen and nitrogen atom of another pyridazinone moieties. The crystal structure of 3a (hydrated) and $\mathbf{3 b}$ (non-hydrated) also revealed that the conformation in both crystals are different due to trapped water in their crystal lattice of hydrated crystal 3a, as shown by variation in bond distances, bond angles and torsions angles (Tables S1 and S4 in SI).

Crystal packing of crystal $\mathbf{3 a}$ and $\mathbf{3 b}$ has been shown in figures 2 and 3 . The figures 4 and 5 had shown the intermolecular contact in molecular packing. Packing is stabilized by $\mathrm{C}-\mathrm{H} \cdots \mathrm{O}, \mathrm{C}-\mathrm{H} \cdots \mathrm{N}, \mathrm{C}-\mathrm{H} \cdots \pi$ and $\pi \cdots \pi$ interactions. Iintermolecular $\pi \cdots \pi$ stacking interactions are observed only in crystal $\mathbf{3 a}$, between cyano

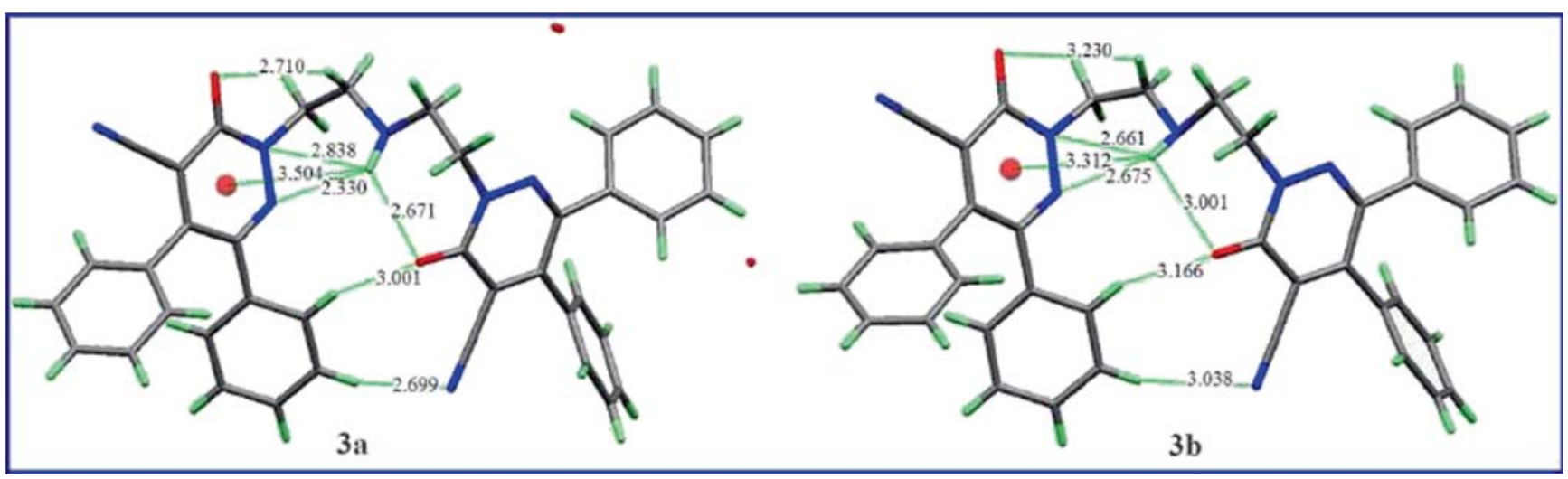

Figure 1. Intramoleculer interactions of molecule $\mathbf{3}$ in (hydrated crystal $\mathbf{3 a}$ and non-hydrated crystal $\mathbf{3 b}$ ). 
group of one of the pyridazinone moiety and heteroaromatic ring of another pyridazinone moiety. Moreover, the intermolecular $\pi \cdots \pi$ stacking interactions are stabilized by combination of $\mathrm{C}-\mathrm{H} \cdots \pi$ and $\mathrm{C}-\mathrm{H} \cdots \mathrm{O}$ interactions in both crystals that occur between centroids of pyridazinone rings. The centroid to centroid distance between pyridazinone moieties in crystal 3a was found to be $3.75 \AA$ and in crystal $\mathbf{3 b}$ it was found to be $3.72 \AA$. This difference may be influenced by the fact that in crystal $\mathbf{3 b}$, a large number of $\mathrm{C}-\mathrm{H} \cdots \pi$ interactions are present compared to crystal 3a. Further,

Table 1. Crystallographic details of crystal (3a and $\mathbf{3 b}$ ).

\begin{tabular}{|c|c|c|}
\hline Identification code & $3 \mathbf{a}$ & $3 b$ \\
\hline Empirical formula & $\mathrm{C}_{38} \mathrm{H}_{29} \mathrm{~N}_{7} \mathrm{O}_{22}(\mathrm{O})$ & $\mathrm{C}_{38} \mathrm{H}_{27} \mathrm{~N}_{7} \mathrm{O}_{2}$ \\
\hline Formula weight & 647.68 & 615.67 \\
\hline Crystal system & Monoclinic & Monoclinic \\
\hline Space group & P 21/n & P 21/c \\
\hline \multicolumn{3}{|l|}{ Cell length } \\
\hline $\mathrm{a}(\AA)$ & $16.2553(12)$ & $17.046(3)$ \\
\hline $\mathrm{b}(\AA)$ & $9.4909(7)$ & $9.3679(12)$ \\
\hline$c(\AA)$ & $23.076(2)$ & $20.873(4)$ \\
\hline \multicolumn{3}{|l|}{ Cell angle } \\
\hline$\alpha\left(^{\circ}\right)$ & 90.00 & 90.00 \\
\hline$\beta\left({ }^{\circ}\right)$ & $105.213(8)$ & $106.887(18)$ \\
\hline$\gamma\left({ }^{\circ}\right)$ & 90.00 & 90.00 \\
\hline Cell volume, $V\left(\AA^{3}\right)$ & $3435.3(5)$ & $3189.4(10)$ \\
\hline D calc $\left(\mathrm{mg} / \mathrm{m}^{3}\right)$ & 1.252 & 1.278 \\
\hline $\mathrm{F}(000)$ & 1352 & 1280 \\
\hline $\mathrm{Z}$ & 4 & 4 \\
\hline$\mu(\mathrm{mm})$ & 0.084 & 0.082 \\
\hline Dx, $\mathrm{g} \mathrm{cm}^{-3}$ & 1.252 & 1.282 \\
\hline \multicolumn{3}{|l|}{ Index range } \\
\hline R-factor (\%) & 9.8 & 9.61 \\
\hline $\mathrm{R}$ int & 0.068 & 0.097 \\
\hline GOF on F2 & 0.99 & 0.914 \\
\hline theta range (deg.) & $25.9^{\circ}-3.3^{\circ}$ & $29.1^{\circ}-3.0^{\circ}$ \\
\hline CCDC No. & 1018592 & 1041164 \\
\hline
\end{tabular}

the molecular packing revealed that intermolecular $\mathrm{C}-\mathrm{H} \cdots \mathrm{O}, \mathrm{C}-\mathrm{H} \cdots \mathrm{N}$ and $\mathrm{C}-\mathrm{H} \cdots \pi$ interaction distances are also different in $\mathbf{3 a}$ and $\mathbf{3 b}$. These differences influenced by trapped water molecules in their crystal lattice, forming $\mathrm{C}-\mathrm{H} \cdots \mathrm{O}$ and $\mathrm{O} \cdots \mathrm{O}$ interactions between water molecules and pyridazinone moieties. Further, the intermolecular differences occur due to the trapped water molecule in crystal lattice of $\mathbf{3 a}$, which influenced the packing pattern in crystal 3a compared to crystal 3b. Thus, it can be concluded that both crystals are different in their conformations.

\subsection{Computational Studies}

To further understand the conformation of molecule $\mathbf{3}$ (in 3a and $\mathbf{3 b}$ crystals), energy in the gaseous state, crystal energy and optimized energy were calculated at $\omega$ B97X-D level of theory with Gaussian 09 package using the 6-31G $(\mathrm{d}, \mathrm{p})$ basis set. The crystal 3a was optimized by removing water molecules from their lattice. The $\omega$ B97X-D contains both exchange and dispersion corrections that play important roles in correctly describing both bond changes and weak interactions. ${ }^{30,31}$ Conformations of molecule $\mathbf{3}$ (3a and $\mathbf{3 b}$ crystals) have already been proposed in solid state. The crystal energies of $\mathbf{3} \mathbf{a}$ and $\mathbf{3} \mathbf{b}$ were found to be $-1253766.90 \mathrm{kcal} / \mathrm{mol}$ and $-1253737.28 \mathrm{kcal} / \mathrm{mol}$ (Table S2 in SI), respectively. The crystal energy of 3b was found to be $29.62 \mathrm{kcal} / \mathrm{mol}$ higher than $\mathbf{3 a}$, which revealed that the crystals are different in their conformations. Further, optimization energy of $\mathbf{3 a}$ and 3b was also calculated for conformational studies by considering the same molecular frame as the crystal structure that showed nearly same energy and same conformation. Table S3 (in SI) shows the comparison of crystallographic and computed intramolecular

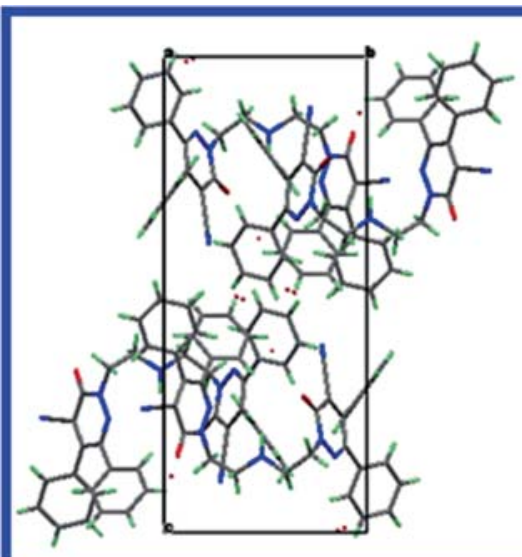

(a)

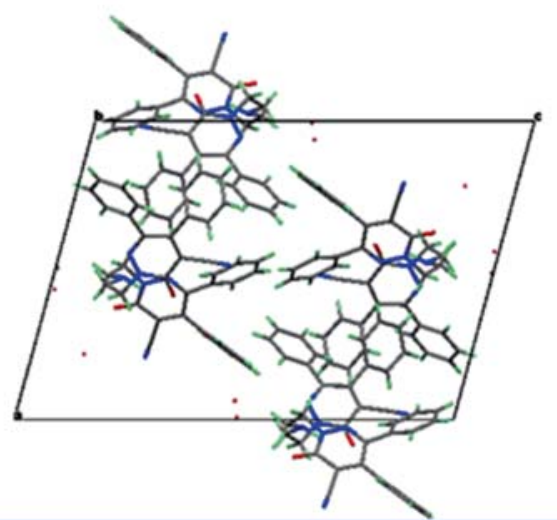

(b)

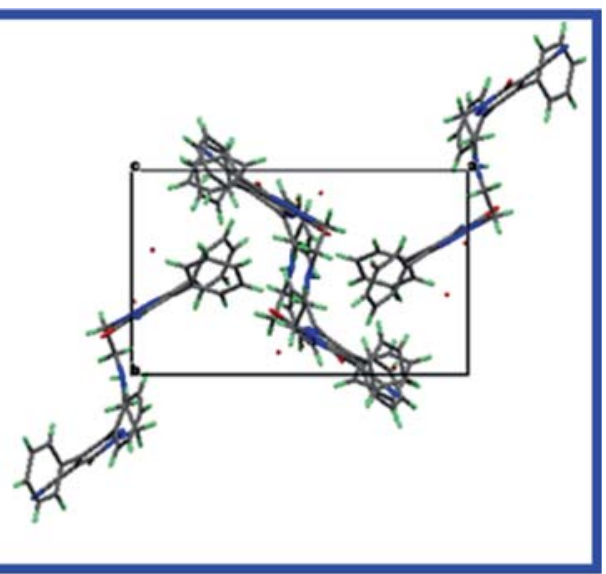

(c)

Figure 2. Packing of crystal 3a along a, b and $\mathrm{c}$ axis. 


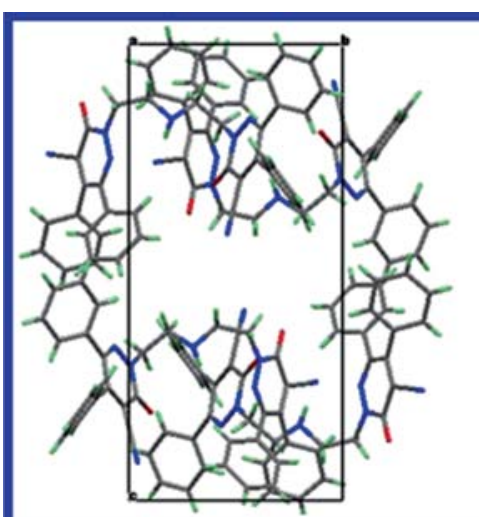

(a)

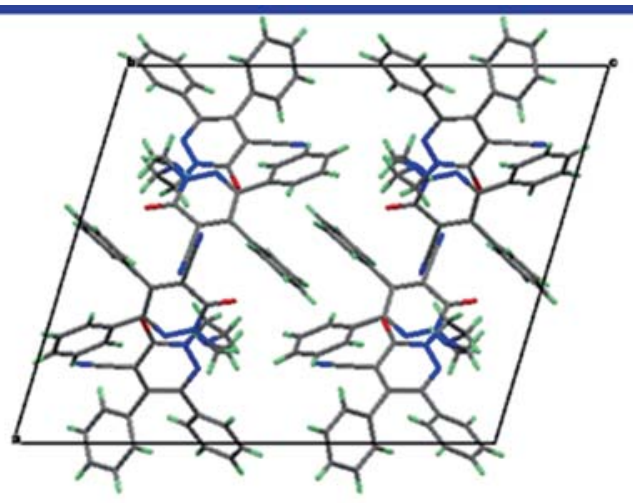

(b)

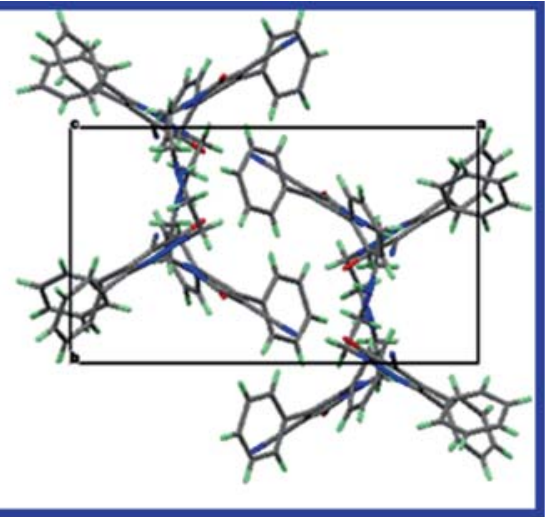

(c)

Figure 3. Packing of crystal $\mathbf{3 b}$ along $\mathrm{a}, \mathrm{b}$ and $\mathrm{c}$ axis.
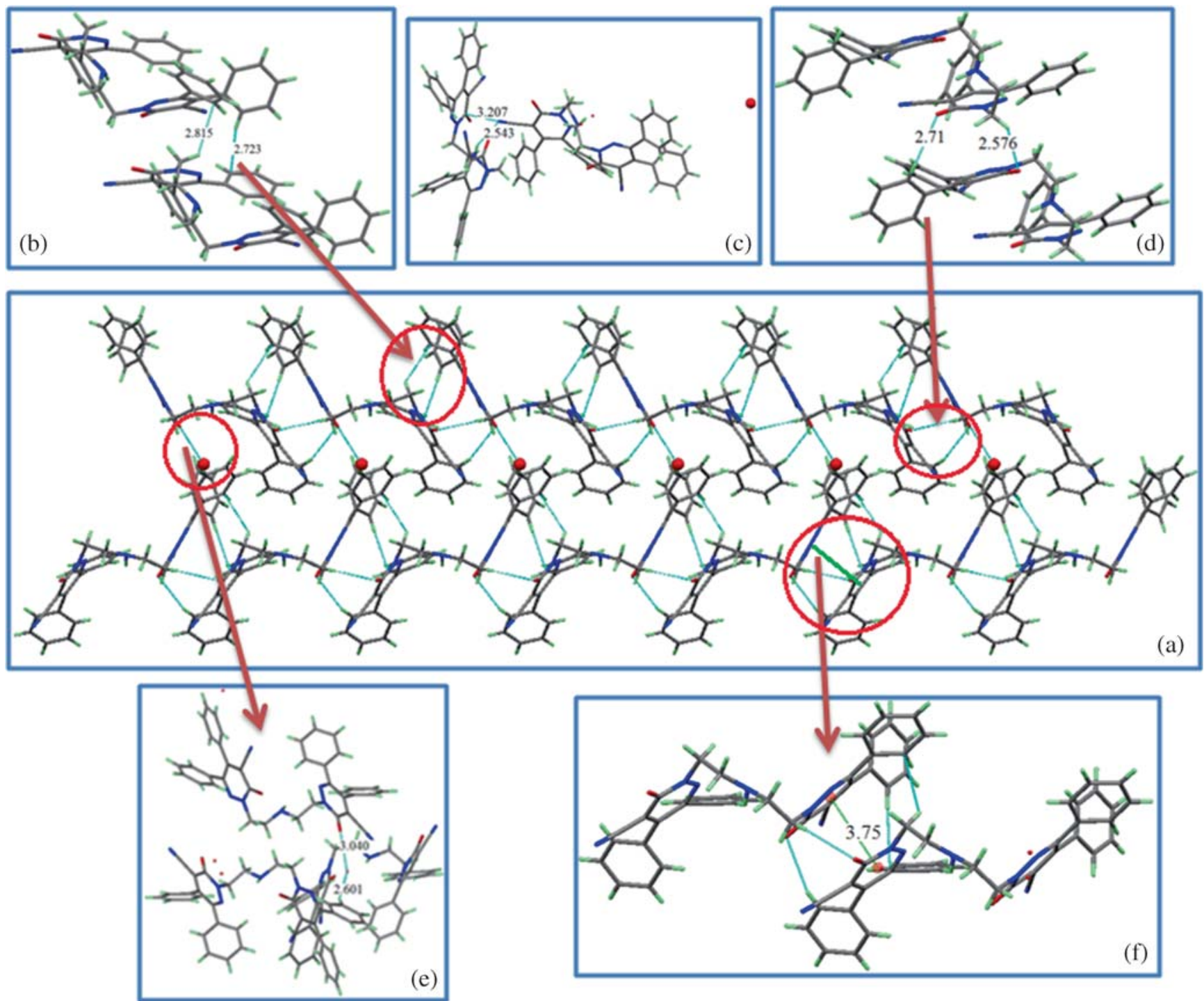

Figure 4. (a) Alternate interaction for $\mathrm{C}-\mathrm{H} \cdots \pi, \mathrm{C}-\mathrm{H} \cdots \mathrm{O}, \mathrm{C}-\mathrm{H} \cdots \mathrm{N}$ and $\pi \cdots \pi$ interactions in crystal 3a; (b) showing distances of intermolecular $\mathrm{C}-\mathrm{H} \cdots \pi$ interactions; (c) showing distances of intermolecular $\mathrm{C}-\mathrm{H} \cdots \mathrm{N}$ and $\pi \cdots \pi$ interactions; (d) and (e) showing intermolecular $\mathrm{C}-\mathrm{H} \cdots \mathrm{O}$ interactions; and (f) showing intermolecular $\pi \cdots \pi$ interactions. 


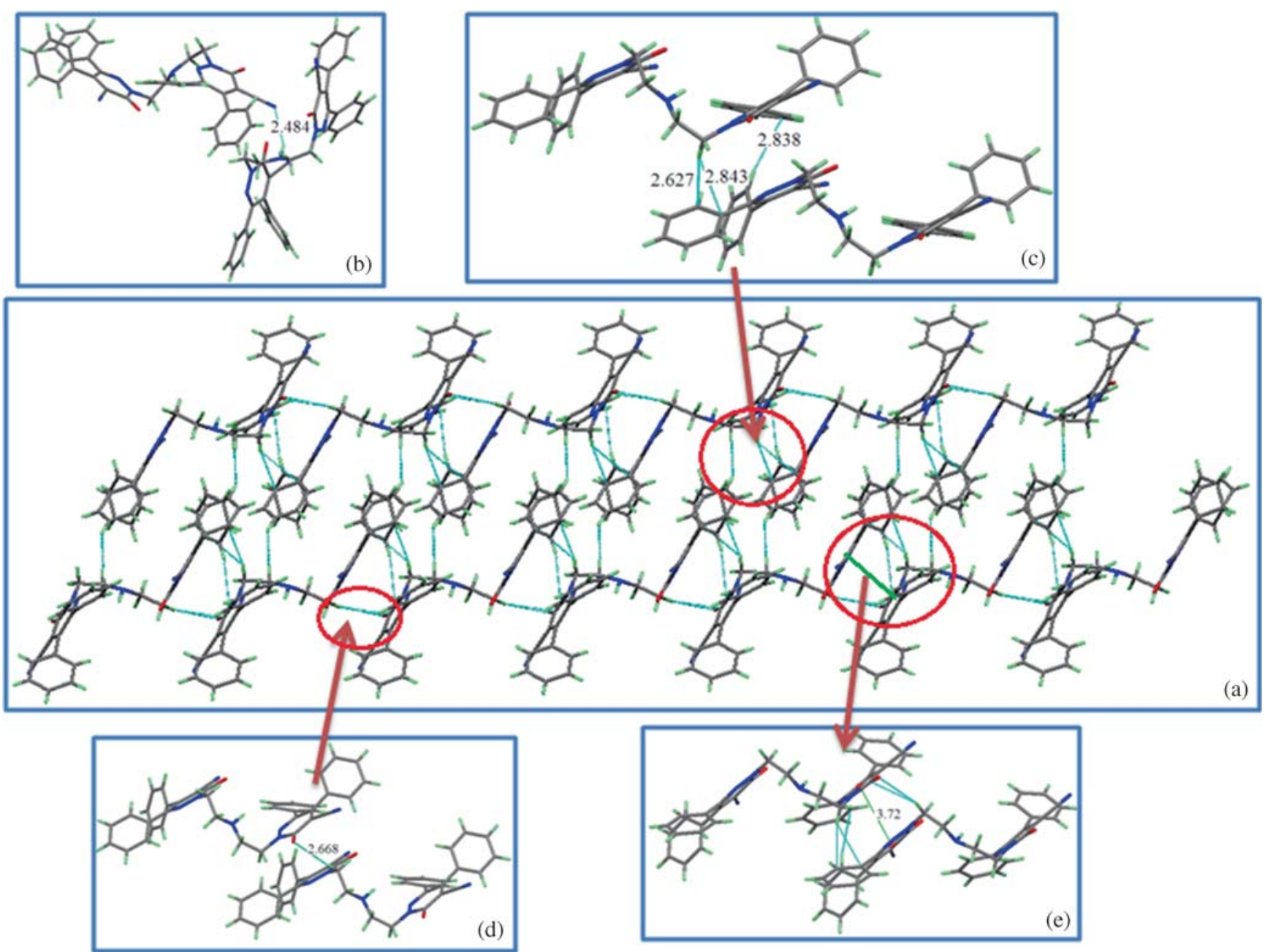

Figure 5. (a) Alternate interaction for $\mathrm{C}-\mathrm{H} \cdots \pi, \mathrm{C}-\mathrm{H} \cdots \mathrm{O}, \mathrm{C}-\mathrm{H} \cdots \mathrm{N}$ and $\pi \cdots \pi$ interactions in crystal 3b; (b) showing distances of intermolecular $\mathrm{C}-\mathrm{H} \cdots \mathrm{N}$ interactions; (c) showing distances of intermolecular $\mathrm{C}-\mathrm{H} \cdots \pi$ interactions; (d) showing distance of $\mathrm{C}-\mathrm{H} \cdots \mathrm{O}$ interactions; (e) showing intermolecular $\pi \cdots \pi$ interactions.

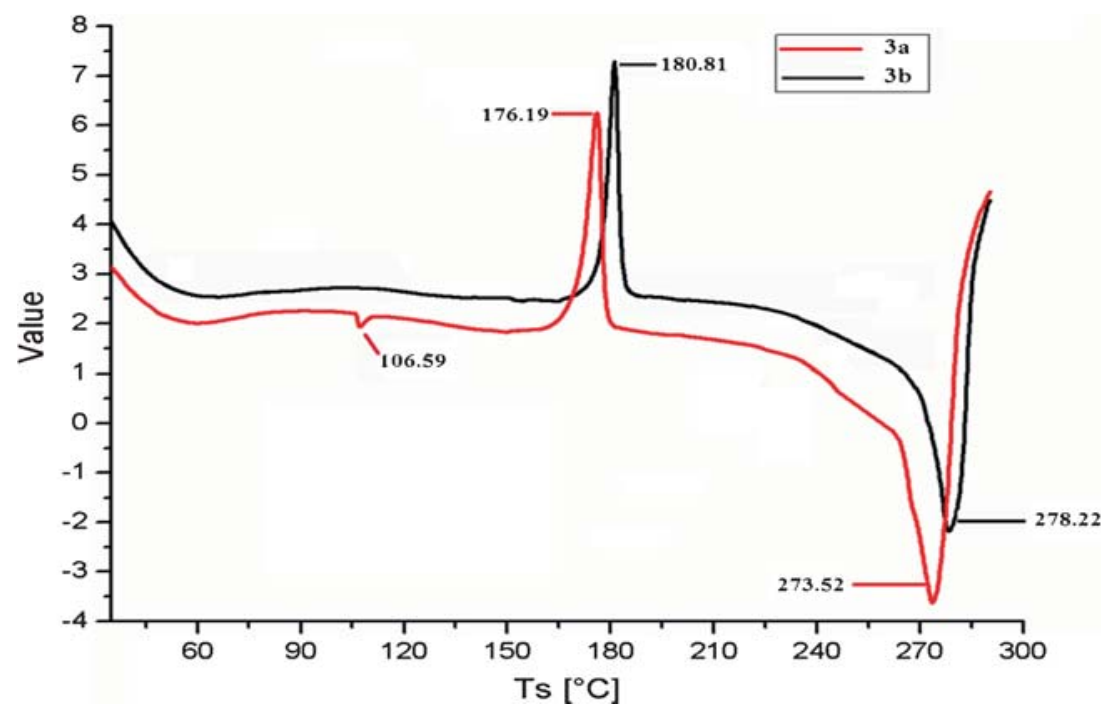

Figure 6. The DSC curves of molecule 3 for hydrated $3 \mathrm{a}$ and non-hydrated $3 \mathrm{~b}$ crystals. 
H-bonded geometry parameters for crystals $\mathbf{3 a}$ and $\mathbf{3 b}$ in folded conformation. To avoid confusion and complexity in numbering, the numbering pattern for the optimized structure is used as a reference to crystal structure. The obtained geometries of both structures suggest that all noncovalent interactions like $\mathrm{N}-\mathrm{H} \cdots \mathrm{N}$, $\mathrm{N}-\mathrm{H} \cdots \pi, \mathrm{N}-\mathrm{H} \cdots \mathrm{O}, \mathrm{C}-\mathrm{H} \cdots \mathrm{N}$ and $\mathrm{C}-\mathrm{H} \cdots \mathrm{O}$ are responsible for the stabilization of the molecule in folded conformation (figure S2 in SI).

\subsection{Differential scanning calorimetry (DSC)}

Differential scanning calorimetry (DSC) is a frequently preferred thermal analytical technique for its ability to provide detailed information on both the physical and energetic properties of a substance, especially on the purity of the component and phase changes upon heating. ${ }^{32}$ Thus, DSC measurements of molecule $\mathbf{3}$ for hydrated $\mathbf{3 a}$ and non-hydrated $\mathbf{3 b}$ crystals were carried out. DSC analysis was performed with slower heating rate, $5^{\circ} \mathrm{C} \mathrm{min}^{-1}$ under dry nitrogen atmosphere, allowing better resolution in the overlap process as indicated in the graph (figure 6). The temperature of range was $35^{\circ} \mathrm{C}-300^{\circ} \mathrm{C}$. For hydrated crystal 3a, DSC curve showed three peaks at $106.59,176.19$ and $273.52^{\circ} \mathrm{C}$. Weak endothermic peak at $106.59^{\circ} \mathrm{C}$ stand obviously for the process of dehydration, one strong exothermic peak at $176.19^{\circ} \mathrm{C}$ is attributed to solid-solid phase transition, and the endothermic peak at $273.52^{\circ} \mathrm{C}$ is attributed to solid-liquid melting transition. Nonhydrated crystal $\mathbf{3 b}$ showed one strong exothermic peak at $180.81^{\circ} \mathrm{C}$ for solid-solid phase transition, and a strong endothermic peak at $278.22^{\circ} \mathrm{C}$ for solid-liquid melting transition. The differences in exothermic peaks of solid-solid phase transitions and endothermic melting transition are due to the differences in their packing pattern due to water molecules present in crystal lattice of hydrated crystal 3a. Thus, DSC melting peak revealed that both crystals are different in their conformations.

\subsection{Hirshfeld Surface Analysis}

The application of Hirshfeld surface analysis could be very valuable in the exploration of the packing modes and intermolecular interactions in molecular crystals. Hirshfeld surface analysis is particularly promising for the visualisation of variations in the environments of the molecules. ${ }^{27}$ The surfaces were shown as transparent to allow visualization of the molecule $\mathbf{3}$ (3a and $\mathbf{3 b}$ crystals) for which they were calculated. Both crystals are illustrated in figure S3 (in SI), where surfaces are shown mapped over $\mathrm{d}_{\text {norm }}$, shape index and curvedness. Complementary regions are visible in the fingerprint plots where one molecule acts as the donor $\left(d_{e}>d_{i}\right)$ and the other as an acceptor $\left(\mathrm{d}_{\mathrm{e}}<\mathrm{d}_{\mathrm{i}}\right)$. The fingerprint plots could be decomposed to highlight a particular atom pair in close contacts. The two dimensional fingerprint plots for molecule 3 revealed that both crystals illustrate significant differences between the intermolecular

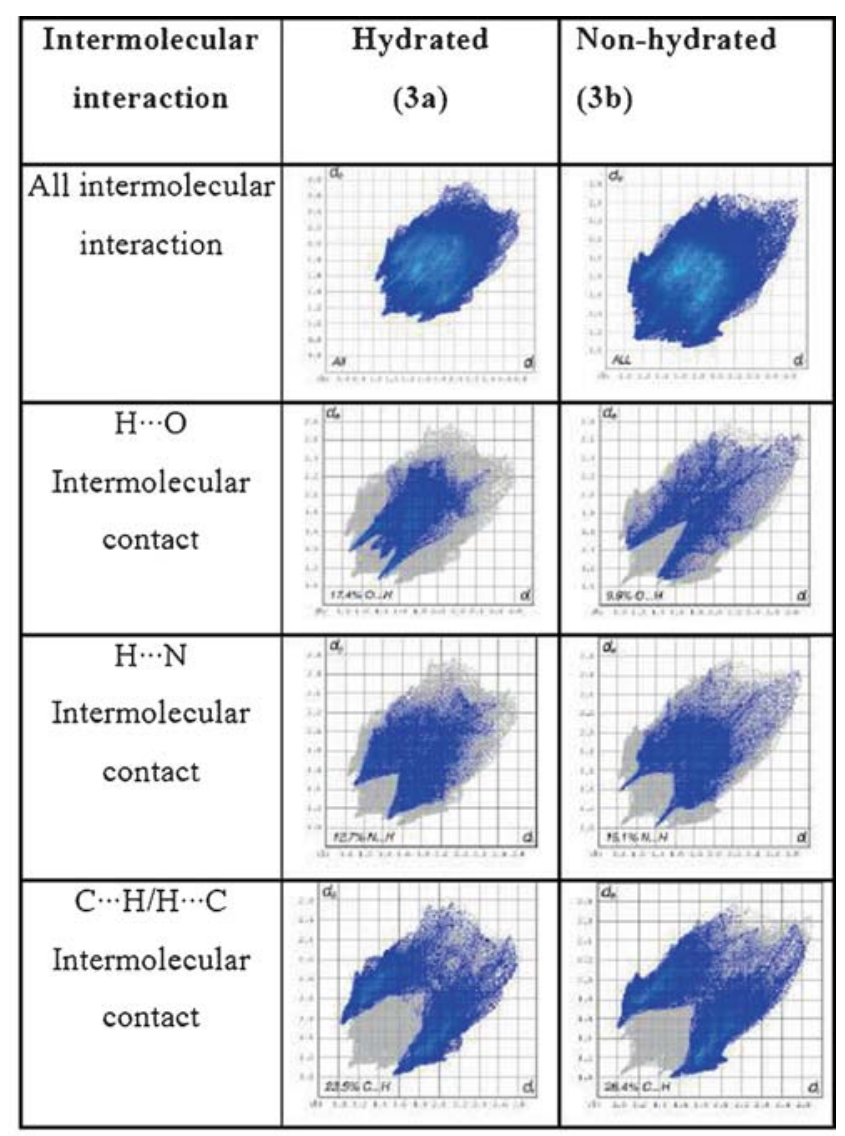

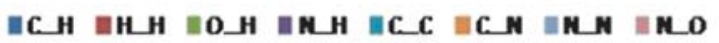

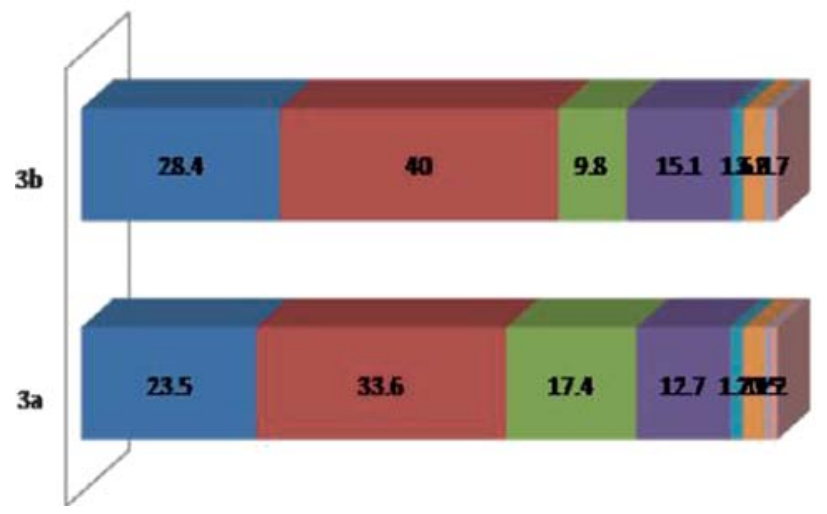

Figure 7. Hirshfeld surface and two-dimensional fingerprint plots for molecule $\mathbf{3}$ (hydrated $\mathbf{3} \mathbf{a}$ and non-hydrated $\mathbf{3 b}$ crystals). 
interaction patterns, due to the significant differences in their conformations.

The hydrated (3a) and non-hydrated (3b) crystals had shown differences in their $\%$ of intermolecular interactions due to the presence and absence of water molecule in their crystal lattice. The Hirshfeld surface and fingerprint analysis do not show a similar proportion of intermolecular $\mathrm{O} \cdots \mathrm{H}$ interactions in the two crystals, i.e., $17.4 \%$ in $\mathbf{3 a}$ and $9.8 \%$ in $\mathbf{3 b}$. In both the crystals, $\mathrm{O} \cdots \mathrm{H}$ interactions are represented by a spike having the $\left(\mathrm{d}_{\mathrm{e}}, \mathrm{d}_{\mathrm{i}}\right)$ regions of $(1.12 \AA, 1.4 \AA)$. There was a significant difference between the intermolecular interactions in both crystals in terms of $\mathrm{N} \cdots \mathrm{H}$ interactions $12.7 \%$ and $15.1 \%$ which are assigned as two long spikes in 3a $\left(\mathrm{d}_{\mathrm{e}}=1.1 \AA, \mathrm{d}_{\mathrm{i}}=1.45 \AA\right)$ and $\mathbf{3 b}\left(\mathrm{d}_{\mathrm{e}}=1.21\right.$ $\AA, d_{i}=1.6 \AA$ ), respectively in the fingerprint plots. In Hirshfeld plot, another kind of intermolecular interaction within both the crystals was also observed. The decomposition of the fingerprint plot had shown $\mathrm{C} \cdots \mathrm{H}$ contact $23.5 \%$ in $\mathbf{3 a}$ and $28.4 \%$ in $\mathbf{3 b}$. These give rise to characteristic wings in the region $\left(\mathrm{d}_{\mathrm{e}}, \mathrm{d}_{\mathrm{i}}\right)$ in $\mathbf{3 a}(1.02$ $\AA, 1.48 \AA$ ) and $3 \mathbf{b}(1.1 \AA, 1.6 \AA)$. The $\mathrm{H} \cdot \cdots \mathrm{H}$ contact comprises of $33.6 \%$ in $\mathbf{3 a}$ and $40.0 \%$ in $\mathbf{3 b}$ in the region of (de, di) 3a (1.02 $\AA, 1.01 \AA)$ and $\mathbf{3 b}(1.11 \AA, 1.11 \AA$ ), respectively, and these crystals had also shown many contacts like $\mathrm{C} \cdots \mathrm{C}, \mathrm{N} \cdots \mathrm{N}, \mathrm{O} \cdots \mathrm{N}, \mathrm{O} \cdots \mathrm{C}, \mathrm{O} \cdots \mathrm{O}$ and $\mathrm{C} \cdots \mathrm{N}$ (figure 7).

\subsection{Docking simulation for DNA binding}

Prior to the simulations, all bound ligands, cofactors, and water molecules were removed from the macromolecule (DNA). The macromolecule was checked for polar hydrogen, and torsion bonds of the inhibitors were selected and defined. Gasteiger charges were computed, and the Auto Dock atom types were defined using Auto Dock version 4.2 (the graphical user interface of Auto Dock supplied by MGL Tools). ${ }^{33}$ The Lamarckian genetic algorithm (LGA), considered one of the best docking methods available in Auto Dock, was employed. ${ }^{34,35}$ For docking simulations of molecule $\mathbf{3}$, structures of $\mathbf{3} \mathbf{a}$ and $\mathbf{3 b}$ were docked onto DNA d(CGCGAATTCGCG) $)_{2}$ and DNA (5' D(GAAGCTTC)-3') oligonucleotides retrieved from the Protein Data Bank (PDB IDs: 1BNA and 173D), respectively. ${ }^{36-38}$ To probe the detailed dynamics of the intercalation process as well as to validate force fields in direct binding simulations, we docked the daunomycin drugs using two well-studied DNA fragments.

The DNA binding with compound $\mathbf{3}$ ( $\mathbf{3 a}$ and $\mathbf{3 b}$ structures) occurred through noncovalent interactions like hydrogen bonding, $\pi \cdots \pi$ stacking and hydrophobic interaction in base pairs of minor groove of DNA (figure 8). Table 2 shows the docking score of Daunomycin and compound $\mathbf{3}$ (3a and $\mathbf{3 b}$ structures)

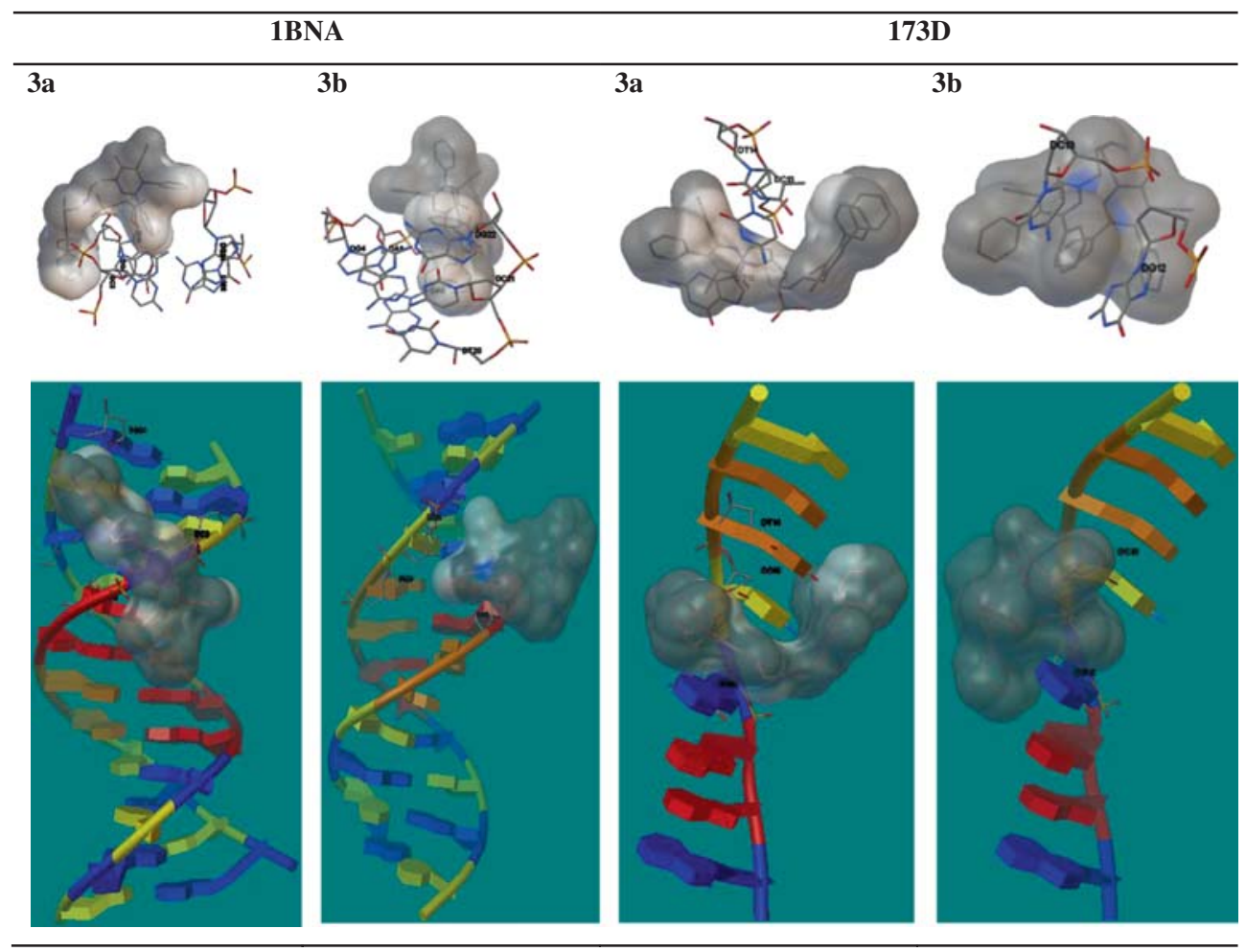

Figure 8. Best docked conformations for molecule $\mathbf{3}$ (hydrated $\mathbf{3 a}$ and non-hydrated $\mathbf{3 b}$ structures) dockings with PDB IDs: 1BNA and 173D DNA fragments. 
Table 2. Docking Simulation results of molecule 3 (3a and $\mathbf{3 b}$ structures) for binding energy of interacting side chain residues with 1BNA and 173D DNA fragments.

\begin{tabular}{|c|c|c|c|c|}
\hline \multirow{2}{*}{$\begin{array}{l}\text { Name } \\
\text { Molecule }\end{array}$} & \multicolumn{2}{|r|}{ 1BNA } & \multicolumn{2}{|r|}{ 173D } \\
\hline & $\begin{array}{l}\text { Binding energy } \\
(\mathrm{kcal} / \mathrm{mol})\end{array}$ & $\begin{array}{l}\text { Interacting side } \\
\text { chain residues }\end{array}$ & $\begin{array}{l}\text { Binding energy } \\
(\mathrm{kcal} / \mathrm{mol})\end{array}$ & $\begin{array}{l}\text { Interacting side } \\
\text { chain residues }\end{array}$ \\
\hline Daunomycin & -7.39 & DC1, DG2 and DG24 & -5.97 & DT6, DT7, DC5 and DG6 \\
\hline 3a & -6.11 & DC3, DG24, DG22, DG4 and DA5 & -6.04 & DC13, DG12 and DT14 \\
\hline $3 \mathbf{b}$ & -5.42 & DA5, DG4, DG22, DC21, DT20 and DA8 & -5.83 & DG4 and DC5 \\
\hline
\end{tabular}

within the minor groove of DNA. The compound $\mathbf{3}$ (3a and $\mathbf{3 b}$ structures) has shown lower binding affinity with DNA (1BNA) fragment and better binding affinity with DNA (173D) fragments as compared to Daunomycin. The conformation of hydrated crystal 3a has shown better binding affinity with both DNA fragments having binding score -6.11 and -6.04 as compared to non-hydrated crystal $\mathbf{3 b}$ conformation with binding score of -5.42 and -5.83 . The docking poses for 3a have shown binding interactions with DC3, DG24, DG22, DG4, and DA5 whereas $\mathbf{3 b}$ has shown DA5, DG4, DG22, DC21, DT20, DA8, DG4 and DC5 within the DNA minor groove of both 1BNA and 173D fragments.

\section{Conclusions}

The diphenyl pyridazinone-based flexible dimer of $\mathbf{3}$ has been synthesized for the first time for conformational studies in crystal in hydrated $\mathbf{3 a}$ and non-hydrated 3b forms. The crystallography studies have shown that diphenyl pyridazinone-based flexible dimer gave folded U shape conformation, seen in crystal structure of $\mathbf{3}$ (3a and $\mathbf{3 b}$ crystals) in spite of long linker due to intramolecular weak noncovalent interactions such as $\mathrm{C}-\mathrm{H} \cdots \pi, \mathrm{N}-\mathrm{H} \cdots \pi, \mathrm{N}-\mathrm{H} \cdots \mathrm{N}, \mathrm{N}-\mathrm{H} \cdots \mathrm{O}, \mathrm{C}-\mathrm{H} \cdots \mathrm{O}$ and $\mathrm{C}-\mathrm{H} \cdots \mathrm{N}$. The docking simulations revealed that molecule 3 has DNA binding ability due to flexibility and intramolecular folding. Therefore, the design of such types of flexible molecules is of interest for structural and medicinal chemists. Further, crystallographic studies have also revealed that from crystal structure of molecule $\mathbf{3}$ is found as two crystals ( $\mathbf{3} \mathbf{a}$ and $\mathbf{3 b}$ ), which showed conformational differences due to the presence and absence of water molecules in their crystal lattice, supported by differences in bond distances, bond angles, torsion angles and packing patterns. Moreover, differences in conformation have been supported by DFT calculations, DSC spectra, Hirshfeld surfaces and two-dimensional fingerprint plots. Due to differences in their conformation and torsion angles of $\mathbf{3} \mathbf{a}$ and $\mathbf{3 b}$, there was a variation in binding energy revealed in docking simulation with DNA.

\section{Supplementary Information (SI)}

Figures S1-S5 and Tables S1-S4 are shown in Supplementary Information, available at www.ias.ac.in/ chemsci.

\section{Acknowledgements}

AKT acknowledges DST India for Grant no. SR/S1/381 OC-42/2012 for financial assistance. Authors thank Pedro Valerga (Departamento de Ciencia de los, Materiales e Ingenieria Metalurgica, Facultad de Ciencias, Campus Universitario del Rio San Pedro, 11510, Puerto Real, Spain) for solved crystals.

\section{References}

1. Desiraju G R 1995 Angew. Chem. 342311

2. Riley K E, Pitonak M, Jurecka P and Hobza P 2010 Chem. Rev. 1105023

3. Hunter C A and Sanders J K M 1990 J. Am. Chem. Soc. 1125525

4. Avasthi K and Amar K 2012 Chem. Bio. Interface 5258

5. David B A and Lluisa P G 2009 Chem. Soc. Rev. 381562

6. Matthieu R, Pablo B, Anton V F and Piet W N M L 2014 Chem. Soc. Rev. 431660

7. Guckian K M, Schweitzer B A, Ren R X F, Sheils C J, Tahmassebi D C and Kool E T $2000 \mathrm{~J}$. Am. Chem. Soc 1222213

8. Wei W, Oreola D, Carolina M R and Peter A K 2001 Annu. Rev. Biophys. Biomol. Struct. 30211

9. Lesley R, Holly F D and Stacey D W 2009 J. Chem. Theory Comput. 51400

10. Petr J, Jirı S, Jir $\mathrm{C}$ and Pavel H 2006 Phys. Chem. Chem. Phys. 81985

11. Jones P, Kinzel O, Pescatore G, Llauger L B, SchultzFademrecht $\mathrm{C}$ and Ferrigno F, United States Patent. US $8,188,084$ B2 (2012)

12. Brandl M, Lindauer K, Meyer M and Sühnel J 1999 Theor. Chem. Acc. 101103

13. Jiang L and Lai L 2002 J. Biol. Chem. 27737732

14. Gutfreund Y M, Margalit H, Jernigan R L and Zhurkin V B 1998 J. Mol. Biol. 2771129

15. Shivakumar K, Vidyasagar A, Naidu A, Gonnadec R G and Sureshan K M 2012 Cryst. Eng. Comm. 14 519 
16. Muthuraman M, Fur Y L, Beucher M B, Masse R, Nicoud J F, George S, Nangia A and Desiraju G R 2000 J. Solid State Chem. 152221

17. Strekowski L and Wilson B 2007 Mutat. Res. 6233

18. Nelson M S, Ferguson R L and Denny A W 2007 Mutat. Res. 62324

19. Browne D T, Eisinger J and Leonard N J 1968 J. Am. Chem. Soc. 907302

20. Rai S K, Srivastava P, Gupta Puerta D M, Valerga P and Tewari A K 2015 Struct. Chem. 26555

21. Maulik P R, Avasthi K, Sarkhel S, Chandra T, Rawat D S, Logsdon B and Jacobson R A 2000 Acta Crystallogr., Sect. C: Cryst. Struct. Commun. 561361

22. Avasthi K, Farooq S M and Tewari A K 2003 Acta Crystallogr., Sect. C: Cryst. Struct. Commun. 5942

23. Singh P, Kumar R, Yadav B K, Khanna R S and Tewari A K 2014 RSC Adv 451239

24. Sheldrick G M 2008 Acta Crystallogr., Sect. A: Found. Crystallogr. 64112

25. Farrugia L J 1999 J. Appl. Crystallogr. 32837

26. Frisch M J, Trucks G W, Schlegel H B, Scuseria G E, Robb M A, Cheeseman J R, Scalmani G, Barone V, Mennucci B, Petersson G A, Nakatsuji H, Caricato M, Li X, Hratchian H P, Izmaylov A F, Bloino J, Zheng G, Sonnenberg J L, Hada M, Ehara M, Toyota K, Fukuda R, Hasegawa J, Ishida M, Nakajima T, Honda Y, Kitao O, Nakai H, Vreven T, Montgomery J A Jr, Peralta J E, Ogliaro F, Bearpark M, Heyd J J, Brothers E, Kudin K N, Staroverov V N, Kobayashi R, Normand J, Raghavachari K, Rendell A, Burant J C, Iyengar S S, Tomasi J, Cossi M, Rega N, Millam M J, Klene M, Knox J E, Cross J B, Bakken V, Adamo C, Jaramillo J, Gomperts R, Stratmann R E, Yazyev O, Austin A J,
Cammi R, Pomelli C, Ochterski J W, Martin R L, Morokuma K, Zakrzewski V G, Voth G A, Salvador P, Dannenberg J J, Dapprich S, Daniels A D, Farkas O, Foresman J B, Ortiz J V, Cioslowski J and Fox D J, (Gaussian, Inc.: Wallingford, CT) (2009)

27. McKinnon J J, Spackman M A and Mitchell A S 2004 Acta Crystallogr., Sect. B: Struct. Sci. 60627

28. Srivastava P, Singh V P, Tewari A K, Puerta C and Valerga P 2012 J. Mol. Struct. 100720

29. (a) Tewari A K, Srivastava P, Singh V P, Singh P, Kumar R, Khanna R S, Srivastava P, Gnanasekaran R, Hobza P 2014 New J. Chem. 38 4885; (b) Tewari A K, Srivastava P, Puerta C and Valerga P 2009 J. Mol. Struct. 92 251; (c) Tewari A K, Srivastava P, Singh VP, Puerta C and Pedro Valerga 2010 ARKIVOC (ix) 127; (d) Dubey R, Tewari A K, Ravikumar K and Sridhar B J 2011 Chem. Crystallogr. 41886

30. Gong Y, Hu Q, Cheng N, Wang T, Xu W, Bi Y and Yu L 2015 J. Mater. Chem. C 33273

31. Zhao Y and Truhlar D G 2008 Acc. Chem. Res. 41157

32. Tiantian L, Yuanyuan R, Bochao W, Weibing D, Songgu W and Junbo G 2014 Front. Chem. Sci. Eng. 855

33. Sanner M F 1999 J. Mol. Graphics Modell. 1757

34. Huey R, Morris G M, Olson A J and Goodsell D S 2007 J. Comput. Chem. 281145

35. Morris G M, Goodsell D S and Hallidayetal R S $1998 \mathrm{~J}$. Comput. Chem. 191639

36. Tabassum S, Al-Asbahy W M, Afzal M, Arjmanda F and Bagchib V 2012 Dalton Trans. 414955

37. Fu X B, Liu D D, Lin Y, Hu W, Mao Z and Le X 2014 Dalton Trans. 438721

38. Kamitori S and Takusagawa F 1994 J. Am. Chem. Soc. 1164154 